Maciej Serowaniec

Uniwersytet Mikołaja Kopernika, Toruń

\title{
Europeizacja tradycyjnych funkcji polskiego parlamentu w świetle postanowień traktatu $z$ Lizbony oraz ustawy kooperacyjnej z 8 października 2010 roku* $^{*}$
}

DOI: http://dx.doi.org/10.12775/SIT.2014.016

W wyniku przystąpienia Rzeczypospolitej Polskiej do Unii Europejskiej nastąpiły istotne przeobrażenia w zakresie definiowana tradycyjnych pojęć, zadań i kompetencji polskiego parlamentu. Zjawisko to jest konsekwencją zmian w systemie sprawowania władzy państwowej, będących następstwem przekazania kompetencji organów władzy na rzecz Unii Europejskiej. Na skutek tego procesu doszło zatem do zmian w zakresie różnych roli odgrywanych przez polski parlament, przemiany obowiązków istniejących dotąd i pojawienia się elementów „europejskiej” funkcji parlamentu. Zjawisko to objęło niemal wszystkie kompetencje parlamentu narodowego, w tym nade wszystko funkcję ustawodawczą i kontrolną ${ }^{1}$.

* Druk publikacji został sfinansowany przez Uniwersytet Mikołaja Kopernika w Toruniu w ramach grantu nr 1652-P.

${ }^{1}$ Por. C. Mik, B. Pawłowski, Glosa do wyroku TK z dnia 12 I 2005 r. (sygn. akt K24/04), „Przegląd Sejmowy” 2005, nr 3 (68), s. 137-138; D. Lis-Staranowicz, J. Galster, O zjawisku europeizacji polskiego prawa konstytucyjnego, „Przegląd Sejmowy" 2010, nr 2 (97), s. 36. 
Nową, dynamiczną rolę parlamentów narodowych w procesie integracji europejskiej wyznaczają również postanowienia art. 12 Traktatu o Unii Europejskiej² ${ }^{2}$ a także dołączone do traktatu z Lizbony Protokół w sprawie roli parlamentów krajowych w Unii Europejskiej (Protokół nr 1) oraz Protokół w sprawie stosowania zasad pomocniczości i proporcjonalności (Protokół nr 2) ${ }^{3}$. Traktat z Lizbony położył szczególny nacisk na udział parlamentów krajowych w demokratycznym rozwoju całej Unii Europejskiej oraz wzmocnieniu demokratycznej legitymizacji unijnych organów ${ }^{4} . \mathrm{Za}$ sprawą regulacji zawartych $\mathrm{w}$ traktacie $z$ Lizbony parlamenty narodowe otrzymują bezpośrednio od unijnych organów projekty aktów ustawodawczych, czuwają zarazem nad poszanowaniem zasady pomocniczości, partycypują w mechanizmach oceniających wykonanie polityki UE $\mathrm{w}$ ramach przestrzeni wolności, bezpieczeństwa i sprawiedliwości oraz uczestniczą w politycznej kontroli Europolu i oceny działalności Eurojustu ${ }^{5}$. Parlamenty narodowe uzyskały również możliwość oddziaływania na tempo oraz zakres procesów integracyjnych, zostały bowiem zaangażowane $\mathrm{w}$ traktatowe procedury rewizji prawa pierwotnego UE oraz procedurę akcesyjną, a także przyczyniają się do rozwoju wielopłaszczyznowej współpracy międzyparlamentarnej, w tym przede wszystkim kooperacji z Parlamentem Europejskim ${ }^{6}$.

Kluczowe znaczenie w sferze wkomponowania polskiego parlamentu w polizbońskie realia ustrojowe odegrała ustawa $z$ października 2010 roku o współpracy Rady Ministrów z Sejmem i Senatem

2 Dz.U. UE 2010/C 83/01, 30 marca 2010 roku.

${ }^{3}$ Zob. Protokół (nr 1) w sprawie roli parlamentów narodowych w Unii Europejskiej oraz Protokół ( $\mathrm{nr}$ 2) w sprawie stosowania zasad pomocniczości i proporcjonalności (Dz.Urz. UE 2010/C 83/206 z 30 marca 2010 roku).

${ }^{4}$ Por. R. Balicki, Parlament narodowy $w$ systemie decyzyjnym Unii Europejskiej (po wejściu $w$ życie postanowień traktatu z Lizbony), w: Instytucje prawa konstytucyjnego $w$ dobie integracji europejskiej: księga jubileuszowa dedykowana prof. Marii Kruk-Jarosz, red. J. Wawrzyniak, M. Laskowska, Warszawa 2009, s. 339 i n.

${ }^{5}$ Por. E. Górniewicz, Wzmocnienie roli parlamentów narodowych $w$ konstrukcji europejskiej, „Biuro Analiz” 2009, nr 23, s. 1-2.

${ }^{6}$ Por. szerzej E. Popławska, Rola parlamentów narodowych $w$ świetle traktatu z Lizbony, „Przegląd Sejmowy” 2010, nr 5(100), s. 157-174. 
w sprawach związanych z członkostwem Rzeczypospolitej Polskiej w Unii Europejskiej (tzw. ustawa kooperacyjna) ${ }^{7}$ oraz znowelizowane, na potrzeby recepcji lizbońskich rozwiązań, regulaminy obu izb ${ }^{8}$. Wprowadzony ustawą kooperacyjną model współpracy pomiędzy Parlamentem a Radą Ministrów w sprawach europejskich ustalił szczegółowe zasady wpływania organów władzy ustawodawczej na polską politykę w sprawach unijnych.

Trudno jest uznać jako przejaw realizacji klasycznej funkcji ustawodawczej parlamentu procedurę implementacji prawa unijnego do krajowego porządku prawnego ${ }^{9}$. W przypadku transpozycji normy unijnej parlament narodowy związany jest bowiem treścią implementowanej normy i nie może suwerenie decydować o zasadniczych kwestiach materialnych czy proceduralnych owej regulacji. Polski parlament, występując stricte w roli podmiotu realizującego wolę unijnego prawodawcy pośredniczy jedynie w procesie implementacji norm unijnych do polskiego porządku prawnego, nie podejmując w tym obszarze w pełni samodzielnych, swobodnych i kreatywnych działań, jak ma to miejsce w przypadku konstytucyjnie określonej procedury legislacyjnej. Należy jednak zwrócić uwagę, że ustawa kooperacyjna z 8 października 2010 roku wzmocniła ustawową procedurę współpracy parlamentu z Radą Ministrów w zakresie tworzenia prawa polskiego wykonującego prawo Unii Europejskiej. Rada Ministrów zobligowana została do przedstawienia Sejmowi i Senatowi, nie rzadziej niż raz na sześć miesięcy, informacji o pracach legislacyjnych związanych $z$ procesem implementacji aktów prawa unijnego, których termin transpozycji upłynął lub upływa w ciągu trzech miesięcy od dnia przedstawienia informacji ${ }^{10}$, tym

7 Zob. Ustawa z dnia 8 października 2010 r. o współpracy Rady Ministrów z Sejmem i Senatem w sprawach związanych z członkostwem Rzeczypospolitej Polskiej w Unii Europejskiej (Dz.U. Nr 213, poz. 1395).

${ }^{8}$ Zob. Regulamin Sejmu RP (M.P. z 2009 r., Nr 5, poz. 47 ze zm.) oraz Regulamin Senatu RP (M.P. z 2000 r., Nr 8, poz. 170 ze zm.).

${ }^{9}$ Por. D. Lis-Staranowicz, Komisja śledcza i Komisja ds. Unii Europejskiej $w$ systemie organów Sejmu, w: Zagadnienia z prawa parlamentarnego, red. M. Granat. Warszawa 2007, s. 231 i n.

${ }_{10}$ Zob. art. 18 ust. 4 Ustawy z dnia 8 października 2010 r. o współpracy Rady Ministrów z Sejmem i Senatem w sprawach związanych z członkostwem Rzeczypospolitej Polskiej w Unii Europejskiej. 
samym parlament sprawuje swoistą kontrolę terminowej implementacji prawa unijnego ${ }^{11}$.

W przedstawionym świetle procedurę implementacji prawa unijnego nie należy rozpatrywać w kategoriach uprawnień parlamentu do stanowienia prawa sensu stricte, lecz jako swoistą powinność parlamentu polegającą na tworzeniu prawa niesprzecznego $\mathrm{z}$ normami prawa unijnego oraz obowiązku wdrożenia norm unijnych do krajowego porządku prawnego. Powinność ta została dodatkowo zabezpieczona w prawie Unii Europejskiej odpowiedzialnością odszkodowawczą państwa członkowskiego w przypadku braku lub niewłaściwej transpozycji prawa unijnego na grunt prawa krajowego ${ }^{12}$.

Zjawisko europeizacji tradycyjnych funkcji polskiego parlamentu odcisnęło swoje piętno nade wszystko w zakresie uprawnień kontrolnych nad Radą Ministrów w sferze realizacji polityki europejskiej. W świetle postanowień obowiązującej ustawy kooperacyjnej, należy stwierdzić, że proces europeizacji tradycyjnych funkcji organów władzy ustawodawczej w procedurze stanowienia prawa Unii Europejskiej zasadniczo realizowany jest przez działania o charakterze informacyjnym oraz opiniodawczym.

W literaturze słusznie podkreśla się, że ustanowienie w parlamencie efektywnych mechanizmów pozyskiwania oraz przetwarzania informacji związanych $\mathrm{z}$ członkostwem w Unii Europejskiej jest tym, co autentycznie przesądza zarówno o europejskiej roli parlamentu, jak też warunkuje pozostałe formy jego współpracy $z$ rządem w sprawach związanych $z$ członkostwem w Unii Europejskiej ${ }^{13}$, przesądzając tym samym o możliwościach wpływania parlamentu

${ }^{11}$ Do przedłożonej informacji półrocznej o udziale Rzeczypospolitej Polskiej w pracach Unii Europejskiej Rada Ministrów zobowiązana została także dołączyć plany prac nad projektami ustaw wykonujących prawo UE, w których określone zostały przez Radę Ministrów terminy ich wniesienia do Sejmu (art. 125 ust. la regulaminu).

12 Por. J. Szymanek, „Funkcja europejska” Sejmu i Senatu jako ustrojowy efekt członkostwa w Unii Europejskiej, w: Polska w Unii Europejskiej, red. M. Kruk, J. Wawrzyniak, Kraków 2005, s. 347 i n.

13 Ibidem, s. 355-358; J. Marszałek-Kawa, Pozycja ustrojowa i funkcje Sejmu Rzeczypospolitej Polskiej po akcesji do Unii Europejskiej, Warszawa 2012, s. 526. 
narodowego na treść unijnych aktów ustawodawczych. W celu zapewnienia parlamentowi możliwie jak najpełniejszego wpływu na procesy decyzyjne ustawa kooperacyjna nałożyła na Radę Ministrów obowiązek przedstawiania na plenum Sejmu i Senatu, nie rzadziej niż raz na 6 miesięcy, rzetelnej informacji o aktualnych działaniach podejmowanych na forum Unii Europejskiej. Przedmiot udzielonej informacji obejmuje nie tylko całość ważniejszych problemów, wobec których aktualnie stoi Unia, ale także istotniejsze działania oraz inicjatywy podejmowane przez organy Wspólnot ${ }^{14}$. Ustawa zobowiązała także rząd do przedstawienia stosownej informacji o bieżących sprawach związanych $z$ członkostwem Rzeczypospolitej Polskiej w UE na każdorazowe żądanie Sejmu, Senatu bądź organu właściwego na podstawie regulaminu Sejmu lub Senatu. $\mathrm{Z}$ ustawowej regulacji wynika więc bezspornie, że Rada Ministrów nie może odmówić tego rodzaju informacji. $Z$ kolei w ramach realizacji szczegółowych obowiązków informacyjnych względem Sejmu i Senatu, Rada Ministrów zobowiązana została do niezwłocznego przekazywania obu izbom polskiego parlamentu projektów aktów UE przyjmowanych na podstawie art. 352 ust. 1 TfUE (art. 7 ust. 2 ustawy) oraz projektów tzw. aktów nieustawodawczych ${ }^{15}$ (art. 8 ust. 1). Ustawa kooperacyjna nałożyła na Radę Ministrów obowiązek przekazania parlamentowi, $\mathrm{z}$ zachowaniem ustawowych terminów ${ }^{16}$ (art. 7 ust. 1 i 2 oraz art. 8 ust. 2), projektów stanowisk RP odnośnie do wymienionych projektów aktów UE wraz z uzasad-

${ }^{14}$ Por. szerzej P. Sarnecki, Wspótpraca Redy Ministrów z Sejmem i Senatem przy wykonywaniu przez Polskę praw członkowskich $w$ UE, „Przegląd Sejmowy 2004", nr 5 (64), s. 13-15.

${ }^{15}$ Projekty aktów prawnych UE inne niż akty, o których mowa w art. 7 ust. 1 i 2 ustawy kooperacyjnej.

${ }^{16}$ Zgodnie $\mathrm{z}$ art. 7 ust. 1 i 2 ustawy kooperacyjnej Rada Ministrów została zobligowana do przekazania Sejmowi projektów stanowisk RP odnośnie do wspomnianych projektów aktów prawnych UE, biorąc pod uwagę terminy wynikające z prawa UE, nie później jednak niż w terminie 14 dni od dnia otrzymania tych projektów. Z kolei w przypadku tzw. aktów nieustawodawczych, jako organu właściwego na podstawie regulaminu Sejmu, Rada Ministrów zobligowana została do przedstawienia na żądanie Komisji SUE projektu stanowiska Rzeczypospolitej odnośnie do tych projektów w terminie 14 dni od dnia otrzymania żądania (art. 8 ust. 1 ustawy). 
nieniem obejmującym ocenę przewidywanych skutków prawnych aktu UE dla polskiego systemu prawa oraz skutków społecznych, gospodarczych i finansowych dla Rzeczypospolitej. Ponadto projekt rządowego stanowiska powinien zawierać informację o rodzaju procedury stanowienia prawa dotyczącej przyjmowanego aktu, trybie jego głosowania w Radzie, a także informację o jego zgodności z zasadą pomocniczości (art. 7 ust. 3). Dołączone do projektu stanowiska RP uzasadnienie prezentować ma parlamentowi następstwa przyjęcia unijnego aktu dla systemu prawa polskiego oraz systemu społeczno-gospodarczego, natomiast dołączona do projektu ocena jego zgodności z zasadą pomocniczości stanowić ma materiał pomocniczy procesie badania zgodności unijnego projektu z zasadą pomocniczości. Z kolei gwarancję udziału polskiego Sejmu i Senatu w procesie monitorowania przebiegu procedur stanowienia prawa unijnego zapewnić ma ustanowienie obowiązku przekazywania przez Radę Ministrów informacji o przebiegu procedur stanowienia prawa Unii Europejskiej oraz o stanowiskach Rzeczypospolitej Polskiej zajmowanych w trakcie tych procedur (art. 10). W ramach procedury konsultacyjnej Rada Ministrów przekazuje również informację o stanowisku, jakie Rada Ministrów ma zamiar zająć podczas rozpatrywania projektu w Radzie UE, wraz z uzasadnieniem stanowiska RP, a także oceną skutków prawnych aktu prawnego dla polskiego systemu prawa oraz skutków społecznych, gospodarczych i finansowych dla RP (art. 11 ust. 1 i 2). Obowiązująca ustawa kooperacyjna, rozszerzając zakres przedmiotowy procedury informacyjnej, zobowiązała Radę Ministrów do przedstawiania parlamentowi informacji na piśmie o stanowisku, jakie Rada Ministrów ma zamiar zająć podczas rozpatrywania projektu w Radzie UE (art. 12 ust. 1) lub Radzie Europejskiej (art. 12 ust. 2) wraz $z$ uzasadnieniem jego stanowiska. Rada Ministrów przekazuje również niezwłocznie obu izbom polskiego parlamentu otrzymane dokumenty UE podlegające konsultacjom z państwami członkowskimi oraz ich oceny sformułowane przez właściwe instytucje lub organy UE z wyłączeniem dokumentów przekazywanych Sejmowi i Senatowi bezpośrednio przez Parlament Europejski, Radę oraz Komisję Europejską (art. 4 ust. 1). Przekazuje również plany pracy Rady oraz oceny rocznych planów legislacyjnych Komisji Europej- 
skiej sporządzone przez Parlament Europejski i Radę UE (art. 5). Została także zobowiązana do przedkładania Sejmowi i Senatowi do rozpatrzenia informacje o stanowiskach innego niż Rzeczpospolita Polska państwa członkowskiego zajętych w trybach, o których mowa w art. 6 ustawy kooperacyjnej. Wymóg ten będzie zatem dotyczył przedłożenia stanowiska innego państwa członkowskiego zajętego w trybie art. 3 ust. 2 Protokołu (nr 36) w sprawie postanowień przejściowych dołączonego do TUE, TfUE oraz TWEA (możliwość zmiany formuły głosowania większością kwalifikowaną w Radzie pomiędzy 1 listopada 2014 roku a 31 marca 2017 roku z tzw. podwójnej większości na formułę nicejską), art. 1 albo 4 decyzji Rady odnoszącej się do wykonania art. 16 ust. 4 TUE i art. 238 ust. 2 TfUE w okresie między 1 listopada 2014 roku a 31 marca 2017 roku i od 1 kwietnia 2017 roku (możliwość czasie trwania okresu przejściowego $z$ tzw. mechanizmu $z$ Joaniny). Obowiązek ten będzie dotyczył również stanowisk innych państw członkowskich występujących z żądaniem przedłożenia Radzie Europejskiej: projektu aktu ustawodawczego przyjętego $\mathrm{w}$ dziedzinie zabezpieczenia społecznego dotyczącego środków niezbędnych do ustanowienia swobodnego przepływu pracowników (art. 48 ust. 2 zd. 1 TfUE), projektu dyrektywy ustanawiającej normy minimalne w zakresie niezbędnym dla ułatwienia wzajemnego uznawania wyroków i orzeczeń sądowych, jak również współpracy policyjnej i wymiarów sprawiedliwości w sprawach karnych o wymiarze transgranicznym (art. 82 ust. 3 zd. 1), projektu dyrektywy ustanawiającej normy minimalne odnoszące się do określania przestępstw oraz kar w szczególnie w zakresie poważnej przestępczości o wymiarze transgranicznym oraz projektu dyrektywy ustanawiającej normy minimalne odnoszące się do określania przestępstw oraz kar w danym obszarze (art. 83 ust. 3 zd. 1 TfUE). Obowiązek informacyjny dotyczy również projektów umów międzynarodowych, których stroną mają być UE lub Europejska Wspólnota Energii Atomowej, projektów decyzji przedstawicieli rządów państw członkowskich zebranych w Radzie, projektów aktów prawnych UE niemających mocy prawnej, w szczególności zaś propozycji wytycznych przyjmowanych w sferze unii gospodarczej i pieniężnej oraz w sferze zatrudnienia, a także aktów UE mających znaczenie dla wykładni lub stosowania prawa UE 
(art. 9 ustawy). Obowiązek ten ma charakter stricte informacyjny, ani bowiem regulamin Sejmu, ani regulamin Senatu nie wiążą z nim szczególnych uprawnień izb.

Wzmocnieniu kontrolnych uprawnień parlamentu w zakresie unijnych procedur decyzyjnych służyć ma również ustawowy obowiązek współpracy Rady Ministrów z Sejmem i Senatem w związku ze sprawowaniem przez przedstawicieli Rady Ministrów prezydencji w Unii Europejskiej (art. 21 ustawy). Rada Ministrów została zobowiązana bowiem do przedstawienia organom właściwym na podstawie regulaminu Sejmu i Senatu (odpowiednio SUE oraz KSUE), z co najmniej miesięcznym wyprzedzeniem, informacji o planowanych priorytetach realizowanych $\mathrm{w}$ ramach polskiej prezydencji (ust. 1 art. 21 ustawy). W okresie sprawowania prezydencji przedstawiciel Rady Ministrów zobowiązany jest również informować sejmową i senacką komisję ds. europejskich o przebiegu sprawowania prezydencji (ust. 2 art. 21 ustawy). Niezwykle ważnym elementem parlamentarnego wymiaru sprawowania prezydencji w Unii Europejskiej w wymiarze ponadnarodowym jest wybór parlamentarnych komisji sektorowych odpowiedzialnych za organizację spotkań roboczych w trakcie sprawowania przez państwo polskie prezydencji w Unii. Ścisła współpraca komisji sektorowych obu izb polskiego parlamentu $\mathrm{z}$ odpowiednimi ministerstwami stanowi, jak pokazuje doświadczenie, fundament tworzenia i realizowania priorytetów w ramach sprawowanej prezydencji ${ }^{17}$.

Co zaś tyczy się uprawnień opiniodawczych polskiego parlamentu, to wraz $z$ formalnym rozpoczęciem procesu legislacyjnego SUE oraz KSUE, jako właściwe na podstawie regulaminu Sejmu i Senatu organy wewnętrzne parlamentu, mogą wyrażać opinię o projekcie unijnego aktu ustawodawczego, projekcie aktu prawnego przyjmowanego na podstawie art. 352 ust. 1 TfUE (art. 7 ust. 4 ustawy) lub projekcie tzw. aktu nieustawodawczego (art. 8 ust. 2 ustawy). Następnie w zależności od fazy zaawansowania unijnego procesu legislacyjnego, mogą one wydać opinię odnośnie do stanowisk zajmowanych przez Radę Ministrów w trakcie procedur

17 Por. szerzej R. Grzeszczak, Prezydencja rotacyjna $w$ Radzie i jej parlamentarny wymiar, „Przegląd Sejmowy” 2011, nr 2 (103), s. 65-81. 
stanowienia prawa UE (art. 10 ust. 2), jak też opinię o stanowisku, jakie Rada Ministrów ma zamiar zająć podczas rozpatrywania tego projektu na posiedzeniu Rady UE (art. 11 ust. 1 oraz art. 12 ust. 1) lub Rady Europejskiej (art. 12 ust. 2). Zdaniem Trybunału Konstytucyjnego wyrażanie przez polski parlament opinii o projektach aktów prawnych UE staje się istotną formą współuczestniczenia $\mathrm{w}$ tworzeniu prawa unijnego. Ustanawiając procedurę opiniowania projektów unijnych aktów prawnych oraz projektów stanowisk Rady Ministrów, władza ustawodawcza uzyskała pewien wpływ na proces rozwoju całej UE, który stanowi ponadto czynnik wzmacniający wiarygodność i demokratyczny mandat organów unijnych. $\mathrm{W}$ ocenie TK zasadnicza zmiana w procedurach tworzenia prawa obowiązującego w RP po przystąpieniu do UE uzasadnia wniosek, że wykonywanie władzy ustawodawczej objęło swym zakresem również możliwość wywierania, choćby nawet tylko pośredniego, wpływu na treść aktów prawa unijnego. Zatem wyrażenie przez SUE opinii w imieniu Sejmu stanowi istotną formę współuczestnictwa w tworzeniu prawa unijnego, będąc swoistym surogatem kompetencji ustawodawczych Sejmu i Senatu. W rezultacie przyjęcia takiego założenia współcześnie funkcja prawodawcza Sejmu, zdaniem TK, składa się $z$ dwóch kompetencji. Pierwsza $z$ nich to uchwalanie prawa krajowego, druga zaś wywieranie, choćby minimalnego, wpływu na treść aktów prawa unijnego ${ }^{18}$.

Jak podkreśla się jednak w literaturze, tradycyjne pojmowanie funkcji prawodawczej parlamentu wydaje się w tym ściśle określonym przypadku niezwykle trudne do przyjęcia, ze względu na pozycję ustrojową organu władzy ustawodawczej, w której to parlament powinien mieć zapewniony realny wpływ na treść stanowionego prawa. Prerogatywa wydawania względnie wiążących opinii przez Sejm oraz niewiążących opinii przez Senat z pewnością nie czyni zadość temu konstytucyjnemu wymogowi ${ }^{19}$. Wydana opinia nie

18 Zob. Wyrok TK z 12 stycznia 2005 r., sygn. K 24/04, OTK ZU 2005, nr 1A, poz. 3.

19 Por. M. Kruk, Tryb przystapienia Polski do UE i konsekwencje członkostwa dla funkcjonowania organów państwa, w: Otrawcie Konstytucji RP na prawo międzynarodowe i procesy integracyjne, red. K. Wójtowicz, Warszawa 2006, s. 153 i n. Nadal aktualne pozostają w tym względzie uwagi poczynione przez 
jest bowiem zabezpieczona w żaden sposób jakąkolwiek sankcją prawną, która występuje w klasycznej funkcji kontrolnej przysługującej parlamentowi. Rada Ministrów nie jest ponadto związana bezwzględnie treścią opinii przedstawionych przez właściwe komisje parlamentarne. Rząd jest jedynie zobowiązany do przedstawienia organom Sejmu własnego stanowiska oraz wyjaśnienia przyczyn, z powodu których nie uwzględnił przedstawionych mu stanowisk (art. 13 ustawy). Jednak zarówno brak możliwości zastosowania wobec Rady Ministrów jakichkolwiek sankcji prawnych, jak i niewiążący charakter przedstawianych opinii skłania do określenia całej tej procedury jako mechanizmu informacji i konsultacji, a nie typowego instrumentu kontroli parlamentarnej, o jakim wspomina Konstytucja RP w art. 95 ust. $2^{20}$. Przyjęcie takiej praktyki ustrojowej pozwala na kwalifikowanie owych opinii jako realizacji przez parlament funkcji kontrolnej z jednej strony, $z$ drugiej zaś należy silnie zaakcentować, iż nadzór ten sprawowany jest wyłącznie $\mathrm{w}$ sferze stanowienia prawa unijnego. Zdaniem Jerzego Jaskierni, z tego względu zasadne wydaje się postrzeganie owej kompetencji parlamentu jako modyfikację klasycznej funkcji kontrolnej realizowanej wobec Rady Ministrów w innych dziedzinach niż prawodawstwo. Stanowi ona wyraz nowej funkcji parlamentu - kontroli tworzenia prawa unijnego ${ }^{21}$. Za sprawą uprawnienia do wyrażania opinii o projektach unijnych aktów prawnych władza ustawodawcza uzyskała jedynie pewien ograniczony wpływ na proces rozwoju całej Unii Europejskiej ${ }^{22}$.

W. Sokolewicza, Formy oddziaływania polskiego parlamentu na prawodawstwo Unii Europejskiej. Wybrane problemy prawne, w: Polska w Unii Europejskiej, s. 74 .

${ }^{20}$ Por. K. Wójtowicz, Funkcja kontrolna Sejmu w zakresie integracji europejskiej, „Przegląd Sejmowy” 2008, nr 3 (86), s. 85-86.

${ }^{21}$ Por. J. Jaskiernia, Akcesja do Unii Europejskiej a konstytucyjny system stanowienia prawa, w: Akcesja do Unii Europejskiej a Konstytucja Rzeczypospolitej Polskiej, red. H. Zięba-Załucka, M. Kijowski, Rzeszów 2002, s. 21-22, s. 59-60; D. Lis-Staranowicz, J. Galster, op.cit., s. 41.

22 M. Dobrowolski, Glosa do wyroku TK z dnia 12 I 2005 r. (sygn. akt K 24/04), „Przegląd Sejmowy” 2005, nr 3 (68), s. 147-148. 
Traktat $z$ Lizbony rozszerzył również kontrolne uprawnienia parlamentów narodowych w unijnym procesie prawodawczym, powierzając im w tym procesie rolę „strażnika zasady pomocniczości”. W ramach ustanowionego mechanizmu wczesnego ostrzegania (kontrola ex ante) parlamenty narodowe, w tym polski Sejm i Senat, uzyskały możliwość efektywnej kontroli zgodności unijnych aktów ustawodawczych z zasadą pomocniczości. Przyjęte w postanowieniach traktatu $z$ Lizbony oraz Protokołu $\mathrm{nr} 2 \mathrm{w}$ sprawie stosowania zasad pomocniczości i proporcjonalności regulacje miały po raz pierwszy $\mathrm{w}$ historii procesu integracyjnego zapewnić parlamentom narodowym możliwość wywierania bezpośredniego wpływu na kształt unijnej legislacji. W ramach kontroli ex ante obie izby polskiego parlamentu mogą bowiem formułować uzasadnione opinie, w których mogą wyrazić swoją negatywną ocenę wobec projektu aktu ustawodawczego. Przy czym dla swojej skuteczności procedura kontroli ex ante wymaga podjęcia przez poszczególne parlamenty narodowe lub ich izby kolektywnego działania, tak aby liczba wydanych uzasadnionych opinii stanowiła określoną większość kwalifikowaną, która określona została w przepisach prawa traktatowego ${ }^{23}$. Na marginesie warto jest wskazać, że od momentu wejścia w życie traktatu $z$ Lizbony polski Sejm wydał 10 uzasadnionych opinii, natomiast Senat wydał 11 uzasadnionych opinii. Obie izby polskiego parlamentu należą zatem do najaktywniejszych spośród państw członkowskich w procedurze badania zgodności unijnych aktów prawodawczych $\mathrm{z}$ zasadą pomocniczości ${ }^{24}$. $Z$ kolei w ramach

${ }^{23}$ W ramach procedury „Żółtej kartki”, aby uzasadnione opinie parlamentów narodowych o niezgodności projektu aktu ustawodawczego z zasadą pomocniczości były skuteczne, konieczne jest, by stanowiły one przynajmniej ${ }^{1}$ / 3 głosów przyznanych parlamentom narodowym (18 głosów), natomiast w przypadku w projektu aktu prawodawczego dotyczącego przestrzeni wolności, bezpieczeństwa i sprawiedliwości, przedłożonego na podstawie artykułu 76 TfUE próg ten wynosi co najmniej 1/4 głosów (14 głosów). Procedura „pomarańczowej kartki” jest uruchamiania, gdy przynajmniej zwykła większość głosów przyznanych parlamentom narodowym sprzeciwia się przyjęciu akt.

${ }^{24}$ Por. K. Wójtowicz, Rola parlamentów narodowych $w$ świetle postanowień traktatów stanowiących podstawę Unii Europejskiej, w: Parlamentarny system rządów. Teoria i praktyka, red. T. Mołdawa, J. Szymanek, M. Mistygacz, War- 
kontroli ex post ustawa kooperacyjna zarówno Sejmowi, jak i Senatowi zagwarantowała za pośrednictwem Prezesa Rady Ministrów wnoszenie skargi do Trybunału Sprawiedliwości UE w sprawie naruszenia przez unijny akt ustawodawczy zasady pomocniczości (art. 17 ustawy). Prezes Rady Ministrów niezwłocznie po otrzymaniu uchwały Sejmu bądź Senatu zobowiązany jest wnieść skargę do Trybunału Sprawiedliwości UE z zachowaniem terminów wynikających $z$ prawa unijnego. Ustawa kooperacyjna nałożyła na Marszałka Sejmu i Marszałka Senatu obowiązek załączenia do podjętej przez Sejm bądź Senat uchwały dokumentu potwierdzającego udzielenie pełnomocnictwa do reprezentowania przed unijnym Trybunałem izby parlamentu wnoszącej skargę w postępowaniu. Prezes Rady Ministrów zobowiązany jest do dołączenia udzielonego mu przez izbę parlamentarną pełnomocnictwa do skargi. Warto podkreślić, iż Prezes Rady Ministrów związany jest treścią przedmiotowej uchwały podjętej przez wyższą lub niższą izbę parlamentu i wyłącznie izba wnosząca zarzut naruszenia zasady pomocniczości przez unijny akt ustawodawczy może zdecydować o jej wycofaniu ${ }^{25}$.

Zjawisko europeizacji klasycznych funkcji parlamentu nie wyczerpuje się wyłącznie ani w procedurze tworzenia nowych norm prawnych, ani tym bardziej w procesie ich wykonywania. Jego swoiste dopełnienie stanowią kompetencje parlamentu do podejmowania decyzji politycznych dotyczących realizacji interesów RP w Unii oraz kompetencje do podejmowania decyzji politycznych dotyczących całej UE. Polski parlament, jako integralna część europejskiej pouvoir constituant, uczestniczy w procedurze tworzenia traktatowych podstaw Unii Europejskiej, zarówno w ramach klasycznej procedury zmiany traktatów, wymagającej ratyfikacji przez wszystkie państwa członkowskie zgodnie $z$ ich konstytucyjnie określonymi wymogami, jak i zmian traktatów dokonywanych w drodze procedur uproszczonych (tzw. procedury kładki), które umożliwiają zmianę określonych

szawa 2012, s. 190-195. Por. szerzej M. Słok-Wódkowska, Zakres przedmiotowy kompetencji parlamentu narodowego do badania zasady pomocniczości $w$ świetle traktatu z Lizbony, „Przegląd Sejmowy” 2010, nr 4 (99), s. 141-152.

${ }^{25}$ Por. R. Chruściak, Skarga Sejmu i Senatu do Trybunału Sprawiedliwości UE - prace parlamentarne, w: Parlamentarny system rządów, s. 296-308. 
części i postanowień traktatów w drodze decyzji Rady Europejskiej lub Rady UE. Tym samym Sejm i Senat dysponują realnym wpływem na zakres oraz tempo procesów integracyjnych.

Wraz z przedstawieniem formalnej propozycji wszczęcia zwykłej procedury zmiany traktatów stanowiących podstawę Unii Europejskiej Rada UE notyfikuje przedłożone propozycje parlamentom narodowym. W toku zwykłej procedury rewizji prawa pierwotnego Sejm i Senat wyłaniają swoich reprezentantów do Konwentu zgodnie $z$ trybem określonym $\mathrm{w}$ regulaminach obu izb. Zgodnie z postanowieniami ustawy kooperacyjnej Sejm i Senat mają również zagwarantowane prawo głosu w przypadku decyzji dotyczącej niezwoływania Konwentu. Przed podjęciem przez Radę Europejską takiej decyzji Prezes Rady Ministrów zobligowany jest bowiem zasięgnąć opinii Sejmu i Senatu (art. 16 ust. 1 ustawy). Należy zauważyć, że Rada Ministrów zobowiązana jest uwzględnić, a więc uczynić podstawą swojego stanowiska w Radzie Europejskiej wyłącznie opinię wydaną przez Sejm. Przedmiotowa opinia nie ma jednak charakteru bezwzględnie wiążącego, ponieważ w przypadku gdy stanowisko RM nie uwzględnia opinii Sejmu, Prezes Rady Ministrów musi niezwłocznie wyjaśnić Sejmowi przyczyny zaistniałych rozbieżności. Przyjęta w ustawie kooperacyjnej konstrukcja zakłada dorozumianą autonomię izb parlamentarnych w zakresie określenia trybu oraz formy wyrażenia opinii, jednak regulamin izby w tej kwestii milczy. Niezbędne zatem staje się określenie na gruncie regulaminu Sejmu, czy podmiotem upoważnionym do wydania opinii jest izba in corpore, czy też jej organ właściwy na podstawie regulaminu Sejmu, a więc de facto SUE. Finalnie obie izby polskiego parlamentu uczestniczą w procedurze ratyfikowania przedłożonych w trybie zwykłym propozycji zmiany traktatów rewizyjnych zgodnie $z$ trybem określonym w art. 89 ust. 1 lub art. 90 Konstytucji RP.

Natomiast w przypadku tzw. uproszczonej procedury zmiany traktatów polski ustawodawca, wzorując się na rozwiązaniach niemieckich, włączył Sejm i Senat w proces akceptacji decyzji podejmowanych w ramach tzw. strukturalnej procedury kładki, przewidzianej w art. 46 ust. 6 TUE, które na gruncie prawa polskiego wymagają ratyfikacji za zgodą wyrażoną w ustawie w trybie przewi- 
dzianym w art. 89 ust. 1 lub art. 90 Konstytucji RP (art. 23 ustawy, nowelizujący ustawę z dnia 14 kwietnia 2000 roku o umowach międzynarodowych ${ }^{26}$ ). W przypadkach zastosowania procedury kładki sensu stricto oraz innych zrównanych $\mathrm{z}$ nimi działań prawnych, zgodnie $z$ brzmieniem art. 14 i art. 15 ustawy kooperacyjnej, decyzję w sprawie stanowiska Rzeczypospolitej Polskiej odnośnie do postanowień, które jednomyślnie zapadły na forum Rady Europejskiej i Rady Unii Europejskiej, podejmuje Prezydent RP na wniosek Rady Ministrów za zgodą wyrażoną w ustawie. Uwzględniając aktywną rolę Sejmu i Senatu w krajowej procedurze podejmowania decyzji o stanowisku Polski w ramach procedury kładki, polski parlament wyposażony został de facto w swoisty instrument weta, który objawia się jako możliwość niewyrażenia przez parlament zgody na ratyfikację przedłożonej propozycji zamiany traktatów ${ }^{27}$.

Przebieg europeizacji klasycznych funkcji parlamentu, za sprawą włączenia organów władzy ustawodawczej w proces wyłaniania kandydatów reprezentujących Rzeczpospolitą w instytucjach unijnych, odnosi się w pewnym zakresie również do funkcji kreacyjnej parlamentu. Co prawda w polskiej praktyce ustrojowej, zgodnie z brzmieniem art. 146 ust. 4 pkt. 9 Konstytucji RP to Rada Ministrów „sprawuje ogólne kierownictwo w dziedzinie stosunków z innymi państwami i organizacjami międzynarodowymi”. Mając jednak na względzie zasadę demokratycznego państwa prawa oraz potrzebę wzmocnienia demokratycznej legitymizacji organów Unii Europejskiej, Rada Ministrów przedkłada każdorazowo sejmowej Komisji do Spraw Unii Europejskiej propozycję kandydatur na stanowiska członka Komisji Europejskiej, członka Trybunału Obrachunkowego, członków Komitetu Ekonomiczno-Społecznego oraz Komitetu Regionów, sędziego Trybunału Sprawiedliwości UE, dyrektora w Europejskim Banku Inwestycyjnym oraz Stałego Przedstawiciela Rzeczypospolitej Polskiej przy Unii Europejskiej (art. 19 ustawy). Komisja w terminie 21 dni od dnia przedłożenia propozycji

${ }^{26}$ Zob. Ustawa $\mathrm{z}$ dnia 14 kwietnia 2000 roku o umowach międzynarodowych (Dz.U. Nr 39, poz. 443 ze zm.).

27 Por. J. Barcz, Traktat $z$ Lizbony. Wybrane aspekty prawne działań implementacyjnych, Warszawa 2012, s. 427. 
kandydatur przez Radę Ministrów wyraża w drodze konsultacji opinię co do zgłoszonych kandydatur (art. 20 ust. 2). Wyrażenie przez Komisję opinii jest niezbędne dla podjęcia dalszych kroków zmierzających do desygnowania kandydatów do unijnych instytucji. Jak podkreśla się w literaturze, ustawowe zastrzeżenie uprawnień w zakresie opiniowania kandydatur jedynie do organów Sejmu wynikać może $\mathrm{z}$ zaklasyfikowania tych uprawnień do sfery parlamentarnej kontroli nad działalnością rządu ${ }^{28}$. Należy także odnotować, że w postanowieniach ustawy kooperacyjnej z 8 października 2010 roku doprecyzowany został charakter prawny opinii Komisji o kandydatach na niektóre stanowiska w organach UE. Zgodnie bowiem $z$ art. 20 ust. 4, w przypadku nieuwzględnienia opinii SUE Rada Ministrów zobligowana została do przekazania SUE informacji o desygnowaniu kandydata, którego dotyczyła opinia, wraz z wyjaśnieniem przyczyn nieuwzględnienia opinii. $Z$ przyjętej w ustawie kooperacyjnej konstrukcji można zatem założyć, że opinia SUE zawierająca ocenę danej kandydatury powinna stanowić podstawę decyzji RM przy desygnacji kandydata na stanowisko w unijnych organach. W świetle regulacji ustawowej opinia wyrażona przez Komisję nie ma jednak charakteru bezwzględnie wiążącego, gdyż stanowi ona de facto wyraz woli politycznej SUE jako organu działającego w imieniu Sejmu.

Dostosowanie krajowych regulacji do nowych rozwiązań proceduralnych zaproponowanych $\mathrm{w}$ traktacie $\mathrm{z}$ Lizbony, w tym przede wszystkich uchwalenie nowej ustawy kooperacyjnej oraz nowelizacja regulaminów obu izb, korzystnie wpłynęło na intensyfikację zaangażowania Sejmu i Senatu w unijny proces decyzyjny oraz wzmocniło pozycję polskiego parlamentu na arenie europejskiej. Czerpiąc z dziewięcioletnich doświadczeń wynikających z członkostwa Rzeczypospolitej Polskiej w Unii Europejskiej oraz wychodząc

${ }^{28}$ Por. P. Sarnecki, op.cit., s. 25. Na kontrolny charakter uprawnienia Komisji do spraw Unii Europejskiej do opiniowania kandydatów na niektóre stanowiska w UE zwraca także uwagę K. Wójtowicz, Funkcja kontrolna, s. 87-88; M. Serowaniec, Uczestnictwo polskiego parlamentu $w$ aktualnej fazie rozwoju europejskiego procesu prawotwórczego, w: Dwadzieścia lat transformacji ustrojowej $w$ Polsce, red. M. Zubik, Warszawa 2010, s. 399. 
naprzeciw nowym wyzwaniom stawianym parlamentom narodowym przez Unię Europejską, polski ustawodawca w nowej ustawie kooperacyjnej w sposób konsekwentny wzmocnił rolę parlamentów narodowych w unijnym procesie decyzyjnym. W wyniku reformy instytucjonalnej Unii wynikającej z wejścia w życie traktatu z Lizbony nastąpił kolejny ważny krok w procesie przeobrażeń w zakresie definiowana klasycznych funkcji parlamentu narodowego. Traktatowe rozszerzenie zakresu prerogatyw parlamentów narodowych w unijnym procesie decyzyjnym spowodowało wykształcenie się nowych, wyodrębnionych form aktywności parlamentu w procesach integracji europejskiej, które coraz bardziej skłaniają do wskazania nowej - „europejskiej” funkcji parlamentów narodowych.

Należy zwrócić przy tym uwagę, że postanowienia traktatu z Lizbony oraz dołączonych do niego Protokołów gwarantują Senatowi $\mathrm{RP}$ pozycję równą Sejmowi w zakresie parlamentarnej kontroli w sferze tworzenia prawa Unii Europejskiej ${ }^{29}$. Zatem w polskim porządku konstytucyjnym, w którym funkcjonujący model parlamentaryzmu oparty jest na tzw. dwuizbowości asymetrycznej, a Konstytucja RP z 2 kwietnia 1997 roku. odmawia Senatowi prawa do wykonywania funkcji kontrolnej, wejście w życie traktatu z Lizbony spowodowało, że „izba wyższa, mimo ograniczonego wpływu na wykonywanie najczęściej wyróżnianych funkcji parlamentu: ustawodawczej, kontrolnej i kreacyjnej, zyskuje znaczący, aby nie powiedzieć równy udział w realizacji zadań związanych $z$ postępującym procesem integracji europejskiej”30. Argument ten może stać się w przyszłości ważnym przyczynkiem w dyskusji na temat kierunku przekształceń modelu parlamentu dwuizbowego w RP.

Ustawa z dnia 8 października 2010 roku o współpracy Rady Ministrów z Sejmem i Senatem w sprawach związanych z członkostwem Rzeczypospolitej Polskiej w Unii Europejskiej z pewnością ugrun-

${ }^{29}$ Por. M. Stębelski, Rola polskiego parlamentu po transformacji ustrojowej, w: XV lat obowiazywania konstytucji z 1997 r. Księga jubileuszowa dedykowana Zdzisławowi Jaroszowi, red. M. Zubik, Warszawa 2012, s. 153, 158.

${ }^{30}$ Ibidem; A. Pudło, Umocnienie statusu Senatu RP na podstawie traktatu z Lizbony, „Przegląd Sejmowy” 2011, nr 6 (107), s. 47-60. 
towała prounijne procedury partycypacji parlamentu w procesie integracji europejskiej, które prowadzić mają do wzmocnienia roli parlamentu narodowego oraz zwiększenia efektywności współpracy pomiędzy naczelnymi organami władzy państwowej w sprawach związanych z członkostwem Polski w Unii Europejskiej. Dodatkowo ustawa uzupełniła pewne luki prawne występujące we wcześniejszej regulacji ustawowej z 2004 roku oraz uporządkowała wiele zagadnień wynikających wprost $z$ reform instytucjonalnych i proceduralnych wprowadzonych w życie na mocy traktatu lizbońskiego ${ }^{31}$.

Reasumując, nie sposób nie zgodzić się z Janem Galsterem, iż „Konstytucja RP nadal pozostaje obojętna wobec procesu wyodrębnienia się europejskiej funkcji władzy ustawodawczej. Funkcja europejska parlamentu nie jest przecież hipostazą, a zadania w ramach tej funkcji są systematycznie wykonywane"32. Wzmocnienie roli polskiego parlamentu przez konstytucyjne określenie jego prerogatyw w ramach europejskiego procesu decyzyjnego $\mathrm{z}$ pewnością dodatkowo przyczyniłoby się do utrwalenia konstytucyjnych wartości takich jak suwerenność, demokracja i rzetelność działania organów państwowych, które leżą przecież u podstaw zjednoczonej Europy. Jednocześnie konstytucja regulacja tej materii mogłaby stworzyć podstawy dla ewentualnej modyfikacji usytuowania ustrojowego Senatu $\mathrm{RP}^{33}$, ponieważ obecnie brak takiej regulacji konstytucyjnej powoduje, że Senat de facto realizuje zadania kontrolne wobec Rady Ministrów w zakresie spraw unijnych, nie dysponując de iure w tym zakresie ową funkcją kontrolną.

${ }^{31}$ Por. A. Fuksiewicz, Sejm i Senat rok po wejściu $w$ życie traktatu lizbońskiego - dostosowanie do reformy instytucjonalnej, Warszawa 2011, s. 18-20.

${ }^{32}$ D. Lis-Staranowicz, J. Galster, op.cit., s. 44.

${ }^{33}$ Podjęte próby przygotowania i uchwalenia stosownej noweli konstytucyjnej nie zakończyły się powodzeniem. Wprawdzie projekt nowelizacji konstytucji został wniesiony do Sejmu przez Prezydenta RP 12 listopada 2010 roku (druk nr 3598), to nie został on do końca VI kadencji Sejmu rozpatrzony i uchwalony. Por. także Zmiany w Konstytucji RP dotyczące członkostwa Polski w Unii Europejskiej. Dokumenty z prac zespołu naukowego powołanego przez Marszałka Sejmu, Biuro Analiz Sejmowych, Warszawa 2010. 


\title{
STRESZCZENIE
}

\author{
Europeizacja tradycyjnych funkcji polskiego parlamentu \\ $\mathrm{w}$ świetle postanowień traktatu z Lizbony oraz \\ ustawy kooperacyjnej z 8 października 2010 roku
}

Dostosowanie krajowych regulacji do nowych rozwiązań proceduralnych przyjętych w traktacie $z$ Lizbony, w tym przede wszystkich uchwalenie nowej ustawy kooperacyjnej oraz nowelizacja regulaminów obu izb, w znaczący sposób wpłynęło na intensyfikację zaangażowania Sejmu i Senatu w unijny proces decyzyjny oraz wzmocniło pozycję polskiego parlamentu na arenie europejskiej. Czerpiąc $z$ dziewięcioletnich doświadczeń wynikających z członkostwa Rzeczypospolitej Polskiej w Unii Europejskiej oraz wychodząc naprzeciw nowym wyzwaniom stawianym parlamentom narodowym przez Unię Europejską, polski ustawodawca w nowej ustawie kooperacyjnej w sposób konsekwentny wzmocnił rolę parlamentów narodowych w unijnym procesie decyzyjnym. W wyniku reformy instytucjonalnej Unii wynikającej z wejścia w życie traktatu z Lizbony nastąpił również kolejny ważny krok w procesie przeobrażeń w zakresie definiowana klasycznych funkcji parlamentu narodowego. Traktatowe rozszerzenie zakresu prerogatyw parlamentów narodowych w unijnym procesie decyzyjnym spowodowało wykształcenie się nowych form aktywności parlamentu w procesach integracji europejskiej, które coraz bardziej skłaniają do wyodrębnienia nowej - „europejskiej” funkcji parlamentów narodowych.

Słowa kluczowe: europeizacja funkcji parlamentu, Sejm RP, Senat RP, parlament narodowy po traktacie $z$ Lizbony, ustawa kooperacyjna.

\section{SUMMARY}

The Europeanization of the traditional functions of the Polish

Parliament in view the provisions of the Treaty of Lisbon and Act on Cooperation of 8 October 2010

The framework for cooperation of the Government with the Sejm and the Senate in EU matters is defined in the Act of 8 October 2010 (the Cooperation Act), which provides for all changes made by the Treaty of Lisbon. The changes introduced by the Lisbon Treaty have had a twofold 
positive effect on the participation of the Sejm and the Senate in the EU policy-making in Poland. Firstly, these changes have lead to the reflection on and the evaluation of the system of cooperation between Government and the both Houses of the Polish parliaments. This should lead to improving the effectiveness of this cooperation and filling the gaps in the existing law. Secondly, the Treaty has had a positive effect on the role of the Sejm and the Senate in EU policy-making not only through its provisions, but also indirectly - through domestic regulations which have been subsequently adopted. In the course of the adjustment process, national parliaments have managed to gain greater powers. In accordance with this, the question emerges whether of Poland's membership of the European Union should be the traditional competencies of the Polish Sejm and the Senate understood in a different way and has created a new European competency of the Polish parliament.

Keywords: European competency of the Polish parliament, the Sejm, the Senate, the national parliament after the Treaty of Lisbon, the Cooperation Act.

\section{BIBLIOGRAFIA}

Balicki R., Parlament narodowy $w$ systemie decyzyjnym Unii Europejskiej (po wejściu w życie postanowień traktatu z Lizbony), w: Instytucje prawa konstytucyjnego $w$ dobie integracji europejskiej: księga jubileuszowa dedykowana prof. Marii Kruk-Jarosz, red. J. Wawrzyniak, M. Laskowska, Warszawa 2009.

Barcz J., Traktat z Lizbony. Wybrane aspekty prawne działań implementacyjnych, Warszawa 2012.

Chruściak R., Skarga Sejmu i Senatu do Trybunału Sprawiedliwości UE prace parlamentarne, w: Parlamentarny system rzadów. Teoria i praktyka, red. T. Mołdawa, J. Szymanek, M. Mistygacz, Warszawa 2012.

Dobrowolski M., Glosa do wyroku TK z dnia 12 I 2005 r. (sygn. akt K24/04), „Przegląd Sejmowy” 2005, nr 3 (68).

Fuksiewicz A., Sejm i Senat rok po wejściu w życie traktatu lizbońskiego dostosowanie do reformy instytucjonalnej, Warszawa 2011.

Górniewicz E., Wzmocnienie roli parlamentów narodowych $w$ konstrukcji europejskiej, „Biuro Analiz” 2009, nr 23.

Grzeszczak R., Prezydencja rotacyjna $w$ Radzie i jej parlamentarny wymiar, „Przegląd Sejmowy” 2011, nr 2 (103). 
Jaskiernia J., Akcesja do Unii Europejskiej a konstytucyjny system stanowienia prawa, w: Akcesja do Unii Europejskiej a Konstytucja Rzeczypospolitej Polskiej, red. H. Zięba-Załucka, M. Kijowski, Rzeszów 2002.

Kruk M., Tryb przystapienia Polski do UE i konsekwencje członkostwa dla funkcjonowania organów państwa, w: Otrawcie Konstytucji RP na prawo międzynarodowe i procesy integracyjne, red. K. Wójtowicz, Warszawa 2006.

Lis-Staranowicz D., Komisja śledcza i Komisja ds. Unii Europejskiej w systemie organów Sejmu, w: Zagadnienia z prawa parlamentarnego. Materiały z XLVIII Ogólnopolskiego Zjazdu Kół i Zakładów Prawa Konstytucyjnego, Serock 1-3 czerwca 2006 r., red. M. Granat, Warszawa 2007.

Lis-Staranowicz D., Galster J., O zjawisku europeizacji polskiego prawa konstytucyjnego, „Przegląd Sejmowy” 2010, nr 2 (97).

Marszałek-Kawa J., Pozycja ustrojowa i funkcje Sejmu Rzeczypospolitej Polskiej po akcesji do Unii Europejskiej, Warszawa 2012.

Mik C., Pawłowski B., Glosa do wyroku TK z dnia 12 I 2005 r. (sygn. akt K24/04), „Przegląd Sejmowy” 2005, nr 3 (68).

Mik C., Pozycja prawna parlamentów narodowych $w$ Unii Europejskiej $w$ świetle traktatu z Lizbony, „Ruch Prawniczy, Ekonomiczny i Socjologiczny" 2010, z. 2.

Popławska E., Rola parlamentów narodowych $w$ świetle traktatu z Lizbony, „Przegląd Sejmowy” 2010, nr 5 (100).

Pudło A., Umocnienie statusu Senatu RP na podstawie traktatu z Lizbony, „Przegląd Sejmowy” 2011, nr 6 (107).

Sarnecki P., Wspótpraca Rady Ministrów z Sejmem i Senatem przy wykonywaniu przez Polskę praw członkowskich w UE, „Przegląd Sejmowy” 2004, nr 5 (64).

Serowaniec M., Uczestnictwo polskiego parlamentu w aktualnej fazie rozwoju europejskiego procesu prawotwórczego, w: Dwadzieścia lat transformacji ustrojowej $w$ Polsce, red. M. Zubik, Warszawa 2010.

Słok-Wódkowska M., Zakres przedmiotowy kompetencji parlamentu narodowego do badania zasady pomocniczości $w$ świetle traktatu z Lizbony, „Przegląd Sejmowy” 2010, nr 4 (99).

Sokolewicz W., Formy oddziaływania polskiego parlamentu na prawodawstwo Unii Europejskiej. Wybrane problemy prawne, w: Polska w Unii Europejskiej. XLVI Zjazd Katedr i Zakładów Prawa Konstytucyjnego, red. M. Kruk, J. Wawrzyniak, Kraków 2005.

Stębelski M., Rola polskiego parlamentu po transformacji ustrojowej, w: XV lat obowiazywania konstytucji z 1997 r. Księga jubileuszowa dedykowana Zdzisławowi Jaroszowi, red. M. Zubik, Warszawa 2012.

Szymanek J., „Funkcja europejska” Sejmu i Senatu jako ustrojowy efekt członkostwa w Unii Europejskiej, w: Polska w Unii Europejskiej. XLVI Zjazd 
Katedr i Zakładów Prawa Konstytucyjnego, red. M. Kruk, J. Wawrzyniak, Kraków 2005.

Wójtowicz K., Funkcja kontrolna Sejmu w zakresie integracji europejskiej, „Przegląd Sejmowy” 2008, nr 3 (86).

Wójtowicz K., Rola parlamentów narodowych $w$ świetle postanowień traktatów stanowiacych podstawę Unii Europejskiej, w: Parlamentarny system rząów. Teoria i praktyka, red. T. Mołdawa, J. Szymanek, M. Mistygacz, Warszawa 2012. 
